\title{
PENGARUH MEDIA VIRTUAL FIELD TRIP TERHADAP KEMAMPUAN BERPIKIR KRITIS
}

\author{
Eneng Desri Handayani, Suhendar, Billyardi Ramdhan
}

Program Studi Pendidikan Biologi, Fakultas Keguruan dan Ilmu Pendidikan, Universitas Muhammadiyah Sukabumi Jl. R. Syamsudin No. 50, Cikole, Kota Sukabumi, Jawa Barat, Indonesia

*Email: desrisapna12@gmail.com

\begin{abstract}
ABSTRAK
Penelitian ini bertujuan untuk mengetahui bagaimana kemampuan berpikir kritis siswa setelah pembelajaran menggunakan metode Outdoor Learning berbantuan media virtual field trip pada pembelajaran biologi materi ekosistem terumbu karang. Jenis penelitian ini adalah penelitian kuasi eksperimen dengan populasi penelitian 2 kelas yang diambil dari kelas X SMA. Sampel penelitian ini dipilih dengan menggunakan teknik purposive sampling. Desain penelitian yang digunakan dalam penelitian ini yaitu Nonequivalent Control Group Design. Instrumen yang digunakan dalam penelitian ini adalah soal tes sebanyak 7 soal yang masing-masing telah dinyatakan valid dan reliabel. Berdasarkan uji persyaratan data diketahui bahwa data hasil penelitian berdistribusi normal dan kedua kelas memiliki kesamaan varians (homogen). Dari analisis data diketahui bahwa nilai rata-rata posttest siswa kelas eksperimen dengan pembelajaran menggunakan bantuan media Virtual Field Trip adalah 70,76 dan nilai rata-rata posttest siswa kontrol dengan pembelajaran tidak menggunakan media Virtual Field Trip adalah 55,23. Ada perbedaan yang signifikan terhadap hasil belajar siswa, ini dibuktikan melalui uji-Z diperoleh $Z_{\text {hitung }}>Z_{\text {tabel }}(2,13>$ 1,96) maka penelitian ini menolak $\mathrm{H}_{0}$ dan menerima $\mathrm{H}_{1}$. Dengan demikian, dapat disimpulkan bahwa terdapat pengaruh hasil belajar pada kemmampuan berpikir kritis siswa yang mengikuti pembelajaran dengan menggunakan metode Outdoor Learning berbantuan media Virtual Field Trip pada materi ekosistem terumbu karang.
\end{abstract}

Kata Kunci : Berpikir Kritis, Soal Tes, Virtual Field Trip.

\section{ABSTRACT}

This study aims to find out how students' critical thinking skills after learning using Outdoor Learning method assisted by virtual media field trip on learning biology material of coral reef ecosystem. This type of research is quasi experimental research with 2 class research population taken from class X SMA. The sample of this research was chosen by using purposive sampling technique. The research design used in this research is Nonequivalent Control Group Design. The instrument used in this study is a matter of as many as 7 test questions that each have been declared valid and reliable. Based on the data requirement test, it is known that the research data is normally distributed and the two classes have the same variance (homogeneous). From the data analysis it is known that the mean posttest grade of the experimental class with the learning using the Virtual Field Trip media aid is 70.76 and the mean posttest of the control students with the learning not using the Virtual Field Trip media is 55.23. There is a significant difference to student learning outcomes, it is proved by $Z$-test obtained $Z_{\text {count }}(2.13>1.96)$ then this research rejects $\mathrm{H}_{0}$ and receives $\mathrm{H}_{1}$. Thus, it can be concluded that there is influence of learning outcomes on the ability of critical thinking of students who follow the learning method using Outdoor Learning media-assisted Virtual Field Trip on the material of coral reef ecosystem.

Keywords: Critical Thinking, Test Problems, Virtual Field Trip.

PENDAHULUAN
Proses belajar mengajar atau proses
pembelajaran merupakan suatu kegiatan
melaksanakan kurikulum suatu Lembaga Pendidikan,
agar tercapai tujuan Pendidikan. Tujuan Pendidikan
adalah mengantarkan peserta didik menuju pada
perubahan-perubahan tingkah laku baik intelektual,
moral maupun sosial agar dapat hidup mandiri

sebagai individu dan makhluk sosial. Dalam mencapai tujuan tersebut peserta didik berinteraksi dengan lingkungan belajar yang diatur guru melalui proses pembelajaran. Proses belajar mengajar juga sangat berpengaruh terhadap keberhasilan peserta didik dalam memahami materi yang disampaikan oleh guru. Sehingga guru dituntut untuk dapat menggunakan metode dan media yang menarik untuk menarik 
perhatian dan membantu belajar peserta didik terutama pada pembelajaran ekosistem yang mengharuskan belajar di luar ruangan dan lagsung ke lapangan untuk melihat langsung kondisi di lapangan.

Tujuan dari penelitian ini yaitu untuk mengetahui bagaimana kemampuan berpikir kritis siswa setelah pembelajaran menggunakan metode Outdoor Learning berbantuan media virtual field trip pada pembelajaran biologi materi ekosistem terumbu karang

Metode dan Media yang dipakai oleh guru haruslah dapat menjadi media yang dapat membawa peserta didik merasa belajar langsung di lapangan. Selain itu, juga media yag dibuat oleh guru harus mampu membangkitkan pola pikir kritis siswa terhadap lingkungannya. Dari hasil wawancara dengan seorang guru di salah satu sekolah SMAN Kota Sukabumi, ditemukan bahwa tingkat kekritisan siswa dalam menyelesaikan tugas sekolah belum merata pada semua siswa, karena saat ini siswa banyak belajar hanya melalui teori yang ada di buku pegangan saja tanpa mengalami langsung kondisi lingkungan yang sebenarnya. Ini terjadi karena adanya kekhawatiran guru dan orang tua siswa akan adanya kecelakaan di lapangan yang tidak terduga, selain itu juga adanya ketidak setujuan dari orang tua masalah biaya yang dikeluarkan untuk mengikuti perjalanan lapangan tersebut, sehingga akhirnya perjalanan lapangan hamper tidak pernah dilakukan di sekolah. Maka dari itu dengan adanya penelitian ini, yaitu berupaya untuk lebih meningkatkan kemampuan berpikir kritis siswa dengan menggunakan metode outdoor learning berbantuan media virtual field trip.

Dengan kondisi seperti itu, maka salah satu metode yang cocok dipakai dalam pembelajaran ini yaitu metode Outdoor learning yang dibantu dengan media yang bisa melatihkan berpikir kritis yaitu dengan menggunakan media Virtual Field Trip yang akan membawa siswa seperti pada lingkungan sebenarnya tanpa turun langsung ke lingkungan yang sebenarnya. Adapun ciri atau karakteristik dari virtual field trip ini yaitu menghubungkan konten dengan kurikulum untuk mencapai pembelajaran yang terfokus, menciptakan dunia nyata melalui dimensi dan dapat membawa pengalaman menjelajahi.

Kedudukan virtual field trip ada dalam komponen mengajar sebagai salah satu upaya untuk mempertinggi proses interaksi guru-siswa dan interaksi siswa dengan lingkungan belajarnya dengan menggunakan teknologi. Dengan demikian fungsi utama dari media virtual field trip adalah sebagai alat bantu mengajar, yakni menunjang penggunaan metode Outdoor Learning yang dipergunakan guru. Dengan melakukan perjalanan lapangan dirasakan sangat tidak praktis bagi guru dan siswa, karena pada saat melakukan perjalanan lapangan akan menghabiskan banyak waktu, biaya dan terlebih lagi perjalanan lapangan akan sia-sia jika apa yang akan kita lihat di lapangan tidak sesuai dengan keadaan saat sampai di lapangan. Perjalanan lapangan juga sangat beresiko tinggi, karena kondisi alam yang tidak bisa diprediksi dan tidak menentu. Berdasarkan hal tersebut, maka peneliti membuat virtual field trip dalam melakukan pembelajaran.

Virtual field trip pun membuat siswa dapat berpikir kritis, karena pada saat ini biasanya seorang guru hanya memberikan materi di kelas sesuai dengan teori yang ada dan media ini akan membuat siswa tidak berkembang dalam hal berpikir. Media ini juga cocok untuk satu pendekatan pengajaran biologi melalui hasil penyelidikan. Ini menekankan belajar melalui pengalaman dan di mana siswa menemukan informasi, mengajukan pertanyaan yang mengarah ke investigasi dari fenomena yang terjadi dikehidupan nyata, memberikan siswa untuk mencoba memahami konsep-konsep dan prinsip-prinsip yang dipelajari. Bitner (1999) menyimpulkan bahwa penggunaan virtual field trip memberikan pembelajaran berbasis proyek di mana siswa diberi masalah yang mereka harus mencoba untuk memecahkan melalui observasi. Sebuah virtual field trip, mampu mengembangkan kemampuan berpikir yag lebih kritis pada siswa melalui elemen media interaktif. Peran guru sangat penting sebagai fasilitator sehingga tujuan pembelajaran dapat tercapai. Kegiatan belajar mengunakan virtual field trip yang sangat cocok untuk mempromosikan naturalis multiple intelligence.

\section{METODE PENELITIAN}

Jenis penelitian ini adalah penelitian kuasi eksperimen. Dimana dalam penelitian ini terdapat dua variabel, yakni variabel bebas dan variabel terikat dengan kelas kontrol dan kelas eksperimen. Dikatakan sebagai kuasi eksperimen karena kelas kontrol dalam penelitian ini tidak dapat berfungsi sepenuhnya mengontrol variabel-variabel luar yang mempengaruhi pelaksanaan eksperimen (Sugiono, 2016).

Desain penelitian yang digunakan dalam penelitian ini yaitu Nonequivalent Control Group Design. Bentuk desain penelitian penelitian ini kelompok eksperimen maupun kelompok kontrolnya tidak dipilih secara acak (Sugiono, 2016).

Penelitian dilaksanakan di SMAN 3 Kota Sukabumi pada semester genap 2017/2018. Populasi untuk 
penelitian ini yaitu menggunakan dua kelas X SMAN 3 Kota Sukabumi. Variabel dalam penelitian ini terdiri dari dua variable yaitu (1). Variable bebas yaitu metode Outdoor Learning berbantuan media Virtual Field Trip. Sedangkan (2). Variabel terikat yaitu kemampuan berpikir kritis siswa pada materi ekosistem. Berdasarkan desain penelitian yang yang digunakan, maka langkah yang dilakukan adalah sebagai berikut: (1). Tahap Persiapan (2). Tahap Pelaksanaan (3). Tahap Penyelesaian (Sudijono, A, 2011). Instrumen pengambilan data meliputi soal tes yang dibuat untu mengukur kemampuan berpikir kritis siswa. Teknik analisis data dengan menggunakan (Arikunto, S, 2012). (1). Uji validitas, sebelum melakukan penelitian dilakukan terlebih dulu uji coba terhadap soal yang akan digunakan dalam penelitian, sebelumnya soal yang diuji cobakan sebanya 12 soal. Dari hasil uji coba yang dilakukan diperoleh 7 soal yang dinyatakan valid, dan 5 soal yang dinyatakan tidak valid. Soal-soal yang telah dinyatakan valid tersebut selanjutnya dijadikan sebagai alat untuk pengumpulan data. (2). Uji reliabilitas, instrument akan dinyatakan reliabilitas karena nilai reliabilitasnya sebesar 0,68. (3). Tingkat kesukaran, dari hasil uji coba tersebut dari 12 soal yang diuji cobakan 11 soal tingkat kesukarannya "sedang" dan 1 soal memiliki tingkat kesukaran "sukar". (4). Daya pembeda, dari hasil uji didapatkan bahwa daya pembeda "cukup". Teknik analisis data yaitu dengan menggunakan uji Z karena jumlah sampel yang digunakan lebih dari 30 siswa, uji ini digunakan untuk menguji apakah sampel penelitian berdistribusi normal atau homogen. Selanjutnya diuji juga nilai varians dan N-Gainnya.

\section{HASIL DAN PEMBAHASAN}

Penelitian ini dilakukan untuk mengetahui kemampuan berpikir kritis siswa melalui metode Outdoor Learning berbantuan media Virtual Field Trip pada materi Ekosistem. Pengumpulan data pada penelitian ini menggunakan dua instrument. Instrument pertama adalah berupa soal uraian yaitu digunakan untuk memperoleh data mengenai kemampuan berpikir kritis siswa dengan melihat hasil sebelum (pretest) dan sesudah (posttest) kegiatan pembelajaran berlangsung. Soal uraian ini digunakan untuk mendapatkan skor pada setiap subindikator kemampuan berpikir kritis yang kemudian dikonversi kedalam bentuk nilai, kemudian dengan melihat kategori peningkatan nilai pada siswa memakai $N$ gain. Adapun subindikator ini sesuai yang dikemukakan Ennis (2011). Instrumen yang kedua yaitu angket yang digunakan untuk mengetahui tanggapan siswa mengenai penggunaanmtode pembelajaran Outdoor Larning berbantuan media Virtual Field Trip terhadap kemampuan berpikir kritis siswa.

Berdasarkan hasil penelitian, untuk mengetahui pengaruh metode Outdoor Learning berbantuan media Virtual Field Trip terhadap kemampuan berpikir kritis siswa, diperoleh data yang diambil dari tes kemapuan berpikir kritis berupa pretest dan posttes sebanyak 7 soal raian. Data hasil tes diperoleh dari siswa yang melakukan pembelajaran menggunakan metode Outdoor Learning berbantuan media Virtual Field Trip (kelas eksperimen) dan kelompok siswa yang melakukan pembelajaran dengan Direct Instruction (kelas kontrol).

Pretest diberikan sebelum pembelajaran dengan tujuan untuk mengetahui pemahaman awal siswa sebelum pembelajaran dimulai. Setelah pembelajaran dilaksanakan siswa kemudian diberikan posttest dengan tujuan untuk mengetahui kemampuan berpikir kritis siswa. Perhitungan $\mathrm{N}$-Gain bertujuan untuk mengetahui indeks peningkatan kemampuan berpikir kritis siswa sebelum perlakuan dan setelah perlakuan. Berikut disajikan rekapitulasi rata-rata nilai pretest, posttest dan $\mathrm{N}$-Gain di kelas eksperimen dan kontrol.

Tabel. 1 Rekapitulasi Nilai Tes Kemampuan Berpikir Kritis Siswa Kelas Eksperimen dan Kelas Kontrol

\begin{tabular}{l|l|l|l|l|l}
\hline \multirow{2}{*}{ No } & \multirow{4}{*}{ Kelas } & \multicolumn{3}{|c|}{ Rata-rata Nilai } & \multirow{2}{*}{$\begin{array}{l}\text { Keterang } \\
\text { an }\end{array}$} \\
\cline { 3 - 6 } & & Pretest & Posttest & $\begin{array}{l}\text { N- } \\
\text { Gain }\end{array}$ & \\
\hline 1 & Eksperimen & 34,61 & 70,76 & 0,58 & Sedang \\
\hline 2 & Kontrol & 28,92 & 55,23 & 0,38 & Sedang \\
\hline
\end{tabular}

Berdasarkan tabel 1 dapat kita ketahui nilai ratarata Pretest kelas ekperimen memiliki perbedaan dengan nilai rata-rata pretest kelas kontrol, dimana nilai rata-rata pretest kelas eksperimen yaitu 34,62 lebih tinggi dari kelas kontrol yaitu 28,92. Nilai ratarata Posttest kelas eksperimen yaitu 70,76 lebih tinggi dari nilai rata-rata posttest kelas kontrol yaitu 55,23. Kedua perbandingan nilai pretest pada kedua kelas menyatakan kemampuan awalnya sudah berbeda, pada kelas eksperimen lebih tinggi kemampuannya dibandingkan kelas kontrol.

Berdasarkan dari perbandingan nilai rata-rata pretest dan posttest, nilai rata-rata yang diperoleh 
siswa setelah pembelajaran baik di kelas kontrol maupun kelas eksperimen keduanya mengalami peningkatan. Hal ini dapat terlihat dari nilai rata-rata pretest dan posttest dan perbandingan nilai rata-rata $\mathrm{N}$-Gain antara kelas ekperimen dan kelas kontrol yang terdapat pada gambar grafik peningkatan 1 dan 2 .

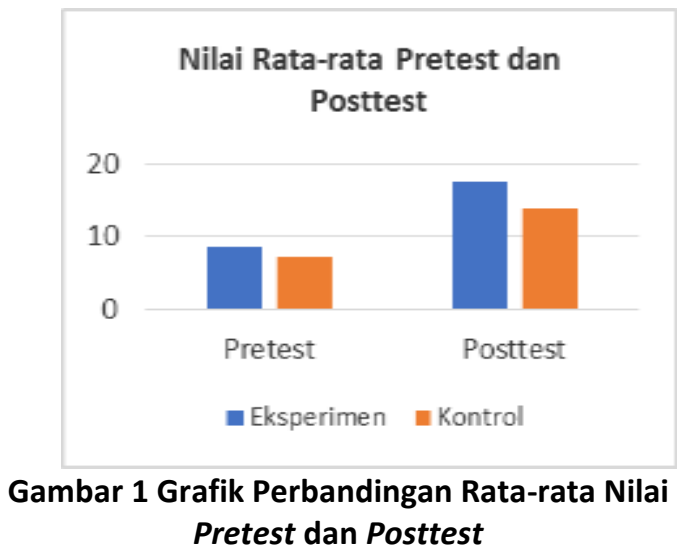

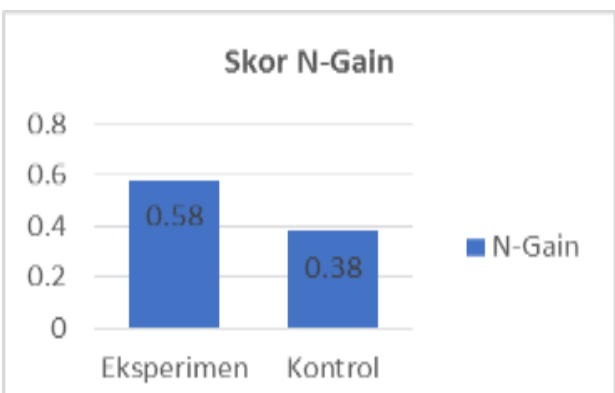

Gambar 2 Grafik Perbandingan Nilai N-Gain

Setelah dilakukan perhitungan hasil nilai pretest dan posttest dari kelas eksperimen dan kelas kontrol, untuk membuktikan apakah metode Outdoor Learning berbantuan media Virtual Field Trip berpengaruh terhadap kemampuan berpikir kritis siswa maka dilakukan uji statistik dari kedua kelas yaitu kelas eksperimen dan kontrol berupa uji normalitas, uji homogenitas dan uji hipotesis. Hasil analisis perhitungan statistik sebagai berikut:

Tabel 2. Hasil Perhitungan Uji Normalitas Kelas Eksperimen

\begin{tabular}{c|c|c}
\hline Uji Normalitas & Hasil & Keterangan \\
\hline$x^{2}=\sum_{i=1}^{k} \frac{(O i-E i)^{2}}{E i}$ & $x^{2}{ }_{\text {hitung }}=3,633$ \\
$x^{2}{ }_{\text {tabel }}=7,81$ & $\begin{array}{c}\text { Sampel berasal dari populasi } \\
\text { yang berdistribusi normal }\end{array}$ \\
\hline
\end{tabular}

Tabel 3. Hasil Perhitungan Uji Normalitas Kelas Kontrol

\begin{tabular}{c|c|c}
\hline Uji Normalitas & Hasil & Keterangan \\
\hline$x^{2}=\sum_{i=1}^{k} \frac{(O i-E i)^{2}}{E i}$ & $x_{\text {hitung }}^{2}=0,455$ & $\begin{array}{c}\text { Sampel berasal dari populasi } \\
\text { yang berdistribusi normal }\end{array}$ \\
\hline
\end{tabular}

Tabel 4. Hasil Uji Homogenitas

\begin{tabular}{c|c|c|c|c}
\hline \multirow{2}{*}{ Uji Homogenitas } & Kelas & $\mathbf{S}^{2}$ & Hasil & Keterangan \\
\hline \multirow{2}{*}{$F=\frac{s^{2} \text { Besar }}{s^{2} \text { Kecil }}$} & Eksperimen & 0,02099 & $\begin{array}{c}\mathrm{F}_{\text {hitung }}=1,21 \\
\mathrm{~F}_{\text {tabel }}=1,95\end{array}$ & $\begin{array}{c}\text { data memiliki varian } \\
\text { yang homogen }\end{array}$ \\
\cline { 2 - 3 } & Kontrol & 0,01726 & \\
\hline
\end{tabular}


Tabel 5. Hasil Perhitungan Uji Z

\begin{tabular}{cc}
\hline Statistik & Hasil Pengolahan \\
\hline$Z_{\text {hitung }}$ & 1,96 \\
$Z_{\text {tabel }}$ & 2,13 \\
\hline Keterangan & $Z_{\text {hitung }}<Z_{\text {tabel }}$ (berbeda signifikan) \\
\hline
\end{tabular}

\section{PEMBAHASAN}

Pada penelitian ini dilakukan pada dua kelas yaitu kelas eksperimen dan kelas kontrol yang dijadikan sampel penelitian. Kelas eksperimen diberikan perlakuan dengan pembelajaran menggunakan metode Outdoor Learning berbantuan media Virtual Field Trip, sedangkan pada kelas kontrol menggunakan pembelajaran langsung (Direct Instruction). Perbedaan perlakuan pada pembelajaran ini bertujuan untuk mengetahu pengaruh penggunaan metode Outdoor Learning terhadap kemampuan media Virtual Field Trip terhadap kemampuan berpikir kritis siswa yang diberlakukan di kelas eksperimen. Pada kelas eksperimen tahapan pertama yang dilakukan dalam melakukan pembelajaran, yaitu siswa diberikan soal pretest yang bertujuan untuk mengetahui seberapa kritis siswa saat sebelum melakukan pembelajaran. Selanjutnya siswa diberikan gambaran mengenai masalah-masalah yang terjadi pada ekosistem terumbu karang, siswa selanjutnya dikelompokkan kedalam beberapa kelompok yang terdiri dari 6-7 siswa. Seperti melakukan kegiatan di luar ruangan siswa terlebih dahulu diberikan LDS (lembar diskusi siswa) agar siswa dapat memahami terlebih dahulu apa saja yang harus mereka amati di dalam media Virtual Field Trip yang akan diberikan, selanjutnya siswa dituntut untuk dapat menganalisis apa saja yang disajikan pada media Virtual Field Trip. Selanjutnya setelah melihat media tersebut mereka melakukan diskusi dengan anggota kelompoknya, diskusi ini bertujuan untuk saling bertukar pikiran antar pemahaman menganalisis siswa antar anggota kelompok. Selanjutnya siswa masing-masing kelompok mempresentasikan hasil diskusi kelompok dengan tujuan antar kelompok dapat berbagi hasil analisis anggota kelompoknya kepada kelompok yang lain, selanjutnya untuk dapat mengetahu apakah dengan metode tersebut dapat menunjukkan peningkatan kemampuan berpikir kritis siswa, maka dengan itu siswa diberikan lembar tes kemampuan berikir kritis (Posttest) dan lembar tanggapan (angket) siswa setelah melakukan pembelajaran dengan metode pembelajaran Outdoor Learning berbantuan media Virtual Field Trip.

Pada kelas kontrol yaitu dengan pembelajaran dengan metode Direct Instruction (pembelajaran langsung). Seperti pada kelas eksperimen guru memberikan tes kemampuan berpikir kritis (pretest) untuk mengetahu seberapa kritis siswa sebelum melakukan pembelajaran. Selanjutnya seperti pembelajran pada umumnya guru menyampaikan tujuan dan dilanjutkan dengan memberikan materi materi dan membagi siswa dalam beberapa kelompok yang berisikan 5-6 orang siswa untuk melakukan diskusi, diskusi ini bertujuan untuk meningkatkan daya pikir siswa saat melakukan pembelajran, setelah melakukan diskusi setia kelompok melakukan presentasi yang bertujuan untuk saling berbagi hasil diskusi setiap anggota kelompok pada kelompok yang lain. Selanjutnya diberikan tes kemampuan berpikir kritis (posttest), tes ini bertujuan untuk mengetahu apakah ada peningkatan pola pikir setelah melakukan pembelajaran.

Pada saat melakukan pembelajaran di kedua kelas pembelajaran diperlakukan sama, namun pada kelas eksperimen ditambahkan atau dibantu dengan adanya media Virtual Field Trip sebagai alat penunjang siswa untuk dapat lebih kritis dalam menanggapi permasalahan yang disajikan. Dari hasil tes kemampuan berpikir kritis siswa, pada kedua kelas mengalami peningkatan pola pikir namun kelas eksperimen lebih tinggi dibandingkan kelas kontrol. 
Pengaruh Metode Outdoor Learning Berbantuan Media Virtual Field Trip Terhadap Kemampuan Berpikir Kritis Siswa

Berdasarkan pengolahan data hasil penelitian adalah pembelajaran dengan menggunakan metode Outdoor Learning berbantuan media Virtual Field Trip pada kelas eksperimen berpengaruh signifikan terhadap kemampuan berpikir kritis siswa. Ini dikarenakan kelas eksperimen yang pembelajarannya menggunakan metode Outdoor Learning berbantuan media Virtual Field Trip siswa akan mendapatkan pengalaman yang membawa siswa seperti turun langsung ke lapangan dibandingkan dengan pembelajaran dengan menggunakan metode Direct Instruction (pembelajaran langsung), pada pembelajaran di kelas eksperimen siswa diajak untuk dapat merasakan pengalaman secara langsung dengan menggunakan bantuan media yang dapat membawa lingkungan ke dalam kelas agar dapat langsung diamati dan dianalisis oleh siswa sehingga siswa akan dapat lebih kritis dengan masalah-masalah yang ada di sekitar mereka, ini sesuai dengan pernyataan dari Winarni (2006) dan Setiawan (2005) dalam Santoso (2010) yang menyatakan bahwa pembelajaran yang meminta siswa untuk memahami atau merumuskan: masalah, tujuan, dan hipotesis, melakukan pengamatan atau penyelidikan, mencari data, serta menganalisis untuk menjawab permasalahan yang telah dirumuskan dapat mengembangkan kemampuan berpikir kritis siswa. Dengan pernyataan tersebut, terbukti dengan pembelajaran menggunakan metode Outdoor Learing berbantuan media Virtual Field Trip dapat menambah kemampuan berpikir kritis siswa karena saat pembelajaran siswa diajak untuk dapat mengamati, melakukan penyelidikan dan menganalisis masalah yang akan mereka pecahkan.

Perbandingan Kemampuan Berpikir Kritis Setiap Indikator Pada Kelas Eksperimen Dan Kontrol

Kemamuan berpikir kritis yang digunakan dalam penelitian ini yaitu dengan menggunakan lima indikator berpikir kritis yang meliputi (1) memfokuskan pertanyaan, (2) mempertimbangkan apakah sumber dapat dipercaya atau tidak, (3) menganalisis pertanyaan, (4) bertanya dan menjawab pertanyaan, serta (5) mengobservasi dan mempertimbangkan suatu laporan hasil observasi.

Hasil dari perhitungan perbandingan setiap indikator berpikir kritis terdapat pada Tabel 6. pada tabel dan gambar tersebut dapat diketahui peningkatan dari setiap indikator berpikir kritis dari hasil analisis pembelajaran yang dilakukan siswa dengan menggunakan metode Outdoor Learning berbantuan media Virtual Field Trip.

Tabel 6. Perbandingan $\mathbf{N}$-Gain Setiap Indikator Kemampuan Berpikir Kritis

\begin{tabular}{l|c|c|c}
\hline \multicolumn{1}{c|}{ Indikator } & $\begin{array}{c}\text { No } \\
\text { Soal }\end{array}$ & $\begin{array}{c}\mathbf{N} \text {-Gain } \\
\text { Kelas } \\
\text { Kontrol }\end{array}$ & $\begin{array}{c}\mathbf{N} \text {-Gain } \\
\text { Kelas } \\
\text { Eksperimen }\end{array}$ \\
\hline Memfokuskan pertanyaan & 1,7 & 0,2 & 0,6 \\
\hline Mempertimbangkan apakah sumber dapat dipercaya atau tidak & 2,5 & 0,3 & 0,3 \\
\hline Menganalisis pertanyaan & 3 & 0,3 & 0,6 \\
\hline Bertanya dan menjawab tentang suatu penjelasan & 4 & 0,4 & 0,7 \\
\hline $\begin{array}{l}\text { Mengobservasi dan mempertimbangkan suatu laporan hasil } \\
\text { observasi }\end{array}$ & 6 & 0,4 & 0,5 \\
\hline \multicolumn{1}{c|}{ Rata-rata } & 0,32 & 0,54 \\
\hline
\end{tabular}

Hasil nilai rata-rata $N$-Gain setiap indikator kemampuan berpikir kritis siswa kelas eksperimen dari tinggi ke rendah adalah (1) bertanya dan menjawab pertanyaan, (2) mengnalisis pertanyaan, (3) memfokuskan pertanyaan, (4) mengobservasi dan mempertimbangkan suatu laporan hasil observasi, serta (5) mempertimbangkan apakah sumber dapat dipercaya atau tidak. Sedangkan pada kelas kontrol masing-masing indikator dari tinggi ke rendah adalah (1) mengobservasi dan mempertimbangkan suatu 
JURNAL PELITA PENDIDIKAN VOL. 6 NO. 1

Handayani, E.D., Suhendar, Ramdhan, B.

Halaman : $116-123$

laporan hasil observasi, (2) bertanya dan menjawab tentang suatu penjelasan, (3) menganalisis pertanyaan, (4) mempertimbangkan apakah sumber dapat dipercaya atau tidak, serta (5) memfokuskan pertanyaan. Untuk pembahasan mengenai data yang diperoleh terhadap kelima indikator kemampuan berpikir kritis yang telah diteliti sebagai berikut:

Memfokuskan pertanyaan

Indikator memfokuskan pertanyaan terdapat pada nomor soal 1 dan 7 soal tersebut menuntut siswa mampu untuk memfokuskan pertanyaan. Contoh soal yang diberikan pada indikator ini yaitu meminta siswa untuk merumuskan masalah yang tersedia pada soal yang menyatakan bahwa air pasang dan ombak besar akibat dari kerusakkan ekosistem terumbu karang. Hal ini yang dapat melatih siswa untuk dapat mengambil langkah apa yang dapat dilakukan untuk menyelesaikan masalah tersebut. Berdasarkan hasil perhitungan nilai rata-rata $\mathrm{N}$-Gain pada kelas eksperimen yaitu sebesar 0,6 dan kelas kontrol sebesar 0,2. Dengan demikian kemampuan berpikir kritis siswa pada indikator memfokuskan pertanyaan jelas terbukti bahwa kelas eksperimen lebih tinggi dibandingkan kelas kontrol. Pada pembelajaran di kelas eksperimen nilai $N$-Gain lebih besar, karena pada pembelajaran menggunakan metode Outdoor Learning membuat siswa merasa turun langsung kelapangan dalam melakukan pembelajaran maka akan meningkatkan fokus dan daya pikir, sehingga siswa yang diperlakukan di kelas eskperimen akan lebih kritis dalam menanggapi suatu masalah, seperti yang diungkapkan oleh Amirudin dkk, 2009; Harini dkk, 2012, Baidowi, 2015 bahwa siswa mampu dan lebih tanggap memberikan beberapa solusi untuk memecahkan permasalahan berdasarkan fakta yang mereka jumpai di lapangan. Terbukti dengan adanya pembelajaran menggunakan metode ini akan mempuat siswa semakin berpikir secara lebih luas dari kelas kontrol yang menggunakan metode pembelajran Direct Instruction (pembelajaran langsung).

Mempertimbangkan apakah sumber dapat dipercaya atau tidak
pISSN : 2338 - 3003

eISSN : 2502 - 3217

Indikator mempertimbangkan apakah sumber dapat dipercaya atau tidak terdapat pada nomor 2 dan 5. Soal tersebut menuntut peserta didik untuk dapat mempertimbangkan apakah sumber dapat dipercaya atau tidak. Salah atu contoh soal yang diberikan pada indikator ini adalah informasi bahwa limbah buangan dari PLTU dapat merusak ekosistem terumbu karang dan dapat berdampak pada hasil tangkapan para nelayan sekitar. Pada soal ini siswa diharapkan mampu mencerna wacana dan mempertimbangkan apakah sumber dapat dipercaya atau tidak. Pada indikator ini nilai $N$-Gain kelas eksperimen yaitu 0,3 dan kelas kontrol 0,3. Artinya ada indikator ini kemampuan siswa kelas eksperimen dan kelas kontrol sama.

Pada indikator kemampuan berpikir kritis ini nilai rata-rata $N$-Gain dari kedua kelas sama karena pada saat pembelajaran kedua kelas yang pembelajaran menggunakan metode Outdoor Learning berbantuan media Virtual Field Trip maupun dengan menggunakan metode Direct Instruction keduanya diajarkan agar siswa dapat mencerna wacana terlebih dahulu sebelum siswa memberikan suatu tanggapan pada suatu permasalahan.

Menganalisis pertanyaan

Indikator menganalisis pertanyaan terdapat pada soal nomor 3. Soal tersebut menuntut peserta didik mampu menganalisis pertanyaan. Contoh soal yang diberikan dengan indikator ini yaitu dengan meminta peserta didik menganalisis dampak apa saja yang dapat ditimbulkan pada ekosistem terumbu karang dari pembuangan limbah ke laut. Hal ini menuntut peserta didik untuk menganalisis pertanyaannya secara ilmiah agar dapat mengetahui apakah pertanyaan tersebut terbukti atau tidak. Pada indikator ini nilai $\mathrm{N}$-Gain kelas eksperimen sebesar 0,6 dan kelas kontrol sebesar 0,3, artinya pada indikator ini kelas eksperimen lebih unggul dari kelas kontrol. Seperti sebelumnya nilai $N$-Gain siswa eksperimen lebih besar dibandingkan dengan nilai dari kelas kontrol karena pada kelas eksperimen siswa merasa senang dan tidak bosan dengan pembelajaran seperti biasanya, pada pembelajaran menggunakan metode Outdoor Learning berbantuan media Virtual Field Trip 
siswa dapat menganalisis permaslahan secara langsung seperti turun ke lapangan secara langsung sehingga siswa akan lebih leluasa menganalisis permasalahan dan dapat memecahkan masalah dengan pemikiran dengan lebih kritis.

Bertanya dan menjawab tentang suatu penjelasan

Indikator bertanya dan menjawab tentang suatu penjelasan terdapat pada soal nomor 4 . Soal tersebut menuntut peserta didik untuk dapat mempertimbangkan hasil observasi yang telah dilakukan. Pada indikator ini kelas eksperimen mendapat nilai $N$-Gain sebesar 0,7 dan kelas kontrol mendapat nilai $N$-Gain sebesar 0,4. Pada indikator ini siswa eksperimen akan lebih bersemangat dalam melontarkan pertanyaan dan menjawab tentang suatu pertanyaan ataupun penjelassan karena pada kelas eksperimen yang melakukan pembelajaran dengan menggunakan metode Outdoor Learning berbantuan media Virtual Field Trip akan lebih termotivasi dalam mengikuti pembelajaran karena melalui metode outdoor study lingkungan di luar sekolah dapat digunakan sebagai sumber belajar. Seperti hal nya dengan menggunakan media Virtual Field Trip pun mereka akan merasa lebih dekat dengan guru sebagai motivator ataupun pemandu saat mereka melakukan pembelajran sehingga mereka akan lebih mudah untuk bertanya dan menjawab.

Mengobservasi dan mempertimbangkan suatu laporan hasil observasi

Indikator mengobservasi dan mempertimbangkan suatu laporan hasil observasi terdapat pada soal nomor 6. Soal tersebut menuntut siswa untuk mampu mnegobservasi dan mempertimbangkan suatu laporan hasil observasi yang telah dilakukan. Pada indikator ini, kelas eksperimen mendapat nilai $\mathrm{N}$-Gain sebesar 0,5 dan kelas kontrol sebesar 0,4.

Dari hasil perbandingan setiap indikator kemampuan berpikir kritis siswa yang lebih unggul dalam setiap indikatornya yaitu kelas eksperimen, ini terbukti bahwa kelas eksperimen dengan pembelajaran menggunakan metode Outdoor Learning berbantuan media Virtual Field Trip lebih membawa siswa pada pengalaman yang baru yang akan membuat mereka dapat merasakan terlibat langsung dengan kejadian yang ada di alam dan siswa lebih dapat mengobservasi dengan leluasa dan siswa pun dapat mempertimbangkan suatu laporan hasil observasi dengan hasil observasi yang telah mereka lakukan. Berbeda dengan kelas kontrol yang melakukan pembelajaran dengan menggunakan metode Direct Instruction (pembelajaran langsung/konvensional) siswa lebih pasif dalam melakukan pembelajaran karena siswa mendapatkan pengalaman belajar dari teori yang disampaikan sehingga siswa tidak dapat terlalu jauh untuk mengkritisi suatu permasalahan.

\section{KESIMPULAN}

Dari hasil penelitian diketahui bahwa pembelajaran dengan menggunakan metode Outdoor Learning berbantuan media Virtual Field Trip berpengaruh terhadap kemampuan berpikir kritis siswa SMAN Kota sukabumi.

\section{DAFTAR PUTAKA}

Arikunto, S, (2012), Prosedur Penelitian Suatu Pendekatan Praktik, Jakarta: Rineka Cipta.

Ennis, R,H, (2011), The Nature of Critical Thinking: An Outline of Critical Thinking Disposition an Abilities, University of Illinois.

Winarni E W, (2006), Pengaruh Strategi Pembelajaran Terhadap Pemahaman Konsep IPA-Biologi, Kemampuan Berpikir Kritis, dan Sikap IImiah Siswa Kelas V SD dengan Tingkat Kemampuan Akademik Berbeda di Kota Bengkulu (Disertasi), Malang: Universitas Negeri Malang. 